\title{
Prognostic evaluation of cases with thoracic trauma admitted to the intensive care unit: 10-year clinical outcomes
}

\author{
(1) Mehtap Pehlivanlar Küçük, M.D.,' ® Ahmet Oğuzhan Küçük, M.D.,2

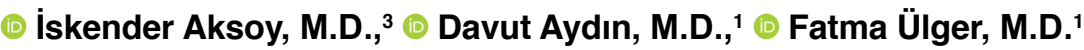

\author{
1'Department of Anesthesiology and Reanimation, Division of Intensive Care Medicine, Ondokuz Mayıs University Faculty of Medicine, \\ Samsun-Turkey \\ ${ }^{2}$ Department of Anesthesiology and Reanimation, Division of Intensive Care Medicine, Faculty of Medicine Karadeniz Technical University, \\ Trabzon-Turkey \\ ${ }^{3}$ Department of Emergency Medicine, Ondokuz Mayıs University Faculty of Medicine, Samsun-Turkey
}

\begin{abstract}
BACKGROUND: Multiple traumas are a leading cause of mortality among young adults worldwide. Thoracic trauma causes approximately $25 \%$ of all trauma-associated deaths. This study aims to determine the independent prognostic factors of mortality in cases with thoracic trauma (isolated or with accompanying organ injuries) who were admitted to the intensive care unit (ICU).

METHODS: We retrospectively reviewed data from patients with thoracic trauma who were admitted to our ICU between 2007 and 2016. After excluding pediatric patients (aged <18 years), the study sample included 564 cases. From the records, we collected the patients' demographical data, comorbid diseases, primary trauma as an indication for ICU admission, other traumas accompanying thoracic trauma, type of thoracic injury, and therapeutic interventions. The study sample was divided into two subsets: survival and non-survival groups. These two groups were compared with regards to first ICU day laboratory results and intensive care scores, mechanical ventilation times, and ICU stay lengths.
\end{abstract}

RESULTS: Of the 8063 patients admitted to the ICU between 2007 and 2016, $616(7.6 \%)$ had thoracic trauma. The median age (min-max) of the 564 patients eligible for this study was 43 (18-87) years. Mortality occurred in 159 (28.1\%) cases, while 405 (7I.8\%) were discharged from the ICU. Multivariate regression analyses were also performed, in which every increment in age was associated with a 1.025 -fold increase in the odds of mortality due to thoracic trauma. Additionally, the presence of central nervous system (CNS) trauma was associated with a 2.147-fold increase, and the presence of pulmonary contusion was associated with a 1.752 -fold increase.

CONCLUSION: Results of this study indicate that advanced age, the presence of pulmonary contusion, and accompanying CNS trauma are independent predictors of mortality in patients with thoracic trauma in the ICU. Our non-invasive approach is further supported by the trauma and injury severity score (TRISS) scoring system, which is one of the latest scoring systems used in trauma cases.

Keywords: Hospital mortality; intensive care unit; thoracic injuries; thoracic trauma; TRISS; Trauma Severity Indices.

\section{INTRODUCTION}

Multiple traumas are often caused by fall from height or motor vehicle accidents. They are among the leading cause of mortality among young adults worldwide. ${ }^{[1]}$ Six percent of patients with trauma have thoracic trauma. Thoracic trauma has been reported to be the cause of approximately $25 \%$ of all trauma-associated deaths. It is considered a contributing factor for mortality in more than another $25 \%$. These data may not be entirely accurate due to the inadequacy of trauma registry systems, and because minor injuries are often discharged without being registered. ${ }^{[2-7]}$ Cases with thoracic traumas and other associated organ injuries often require intensive care because they need to be closely monitored

Cite this article as: Pehlivanlar Küçük M, Küçük AO, Aksoy İ, Aydın D, Ülger F. Prognostic evaluation of cases with thoracic trauma admitted to the intensive care unit: 10-year clinical outcomes. Ulus Travma Acil Cerrahi Derg 2019;25:46-54.

Address for correspondence: Mehtap Pehlivanlar Küçük, M.D.

Ondokuz Mayıs Üniversitesi Tıp Fakültesi, Anesteziyoloji ve Reanimasyon Anabilim Dalı, Samsun, Turkey.

Tel: +90362 - 3121919 E-mail: mehtap_phlvnlr@hotmail.com

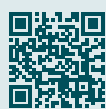

Ulus Travma Acil Cerrahi Derg 2019;25(I):46-54 DOI: 10.5505/tjtes.2018.97345 Submitted: 23.02.2018 Accepted: 16.07.2018 Online: 26.12.2018

Copyright 2019 Turkish Association of Trauma and Emergency Surgery 
due to high mortality rates. ${ }^{[3,8]}$ Indications for intensive care unit (ICU) admission typically include respiratory problems and hemodynamic instability. The most frequently affected anatomical structures in thoracic traumas are particularly the chest wall as well as the lung parenchyma, heart, diaphragm, and aorta. ${ }^{[9]}$ With regards to management of thoracic trauma, conservative approaches are sufficient in $90 \%$ of the cases; however, a small number of patients require surgical interventions, including urgent thoracotomy. ${ }^{[10]}$ Accurate risk stratification in patients with thoracic trauma who are admitted to the ICU is crucial to understand risk factors for late complications and improve the ICU outcomes. Several trauma-scoring systems have been developed to guide triage and predict mortality. This study aimed to identify independent prognostic factors of mortality in cases admitted to the ICU due to thoracic trauma, either isolated or with other organ injuries.

\section{MATERIALS AND METHODS}

The STROBE guideline was used as a guide for this manuscript. In this study, we retrospectively reviewed clinical data from patients admitted to the Anesthesiology and Reanimation ICU due to single or multiple traumas to identify patients with thoracic trauma. Following approval from our university's ethics committee (2016/387), data from patients admitted to the ICU between 2007 and 2016 were collected by reviewing the ICU patient follow-up charts, medical files, and hospital information system.

From the records, we collected the patients' demographical data, comorbid diseases, primary trauma as an indication for ICU admission, other traumas accompanying thoracic trauma, type of thoracic injury and therapeutic interventions, Glasgow coma score (GCS), laboratory results (hemoglobin, creatinine, BUN, sodium, and platelet), inotropic-vasopressor use, injury severity score (ISS), revised trauma score (RTS), trauma and injury severity score (TRISS), mechanical ventilation (MV) state, ICU stay length, and patient outcomes. The diagnosis of thoracic trauma was based on thoracic CT and chest X-ray images. The RTS is a scoring system based on bed-side clinical and physiological data, including the GCS, systolic blood pressure (SBP), and respiratory rate (RR). It is calculated with the following formula: $\mathrm{RTS}=(0.9368 \times \mathrm{GCS})$ $+(0.7326 \times \mathrm{SBP})+(0.2908 \times \mathrm{RR})$. Results yield a value ranging from 0 to 7.8408, with higher scores indicating less severe injury. The ISS is an anatomical scoring system designed for patients with multiple traumas. The region with the highest score from the ISS (i.e., the region where the trauma is most severe or the region most likely to cause mortality) is called the primary trauma region. TRISS is calculated using RTS, ISS, and patient age. ${ }^{[1,12]}$ The study sample was divided into two subsets: survival and non-survival groups. These two groups were compared with regards to first ICU day laboratory results and intensive care scores, MV times, and ICU stay lengths.
All data were analyzed using IBM SPSS V23 (Chicago, USA). The Shapiro-Wilk test was used to determine whether the data were normally distributed. Comparisons of data that were not normally distributed were made with the KruskalWallis test and the Mann-Whitney $U$ test. Categorical data were analyzed with the Pearson chi-square test. The effects of the examined parameters on mortality were investigated with a logistic regression analysis. The ROC analysis was used to calculate the TRISS cut-off score. Non-normally distributed data were presented as median (min-max), while normally distributed data were presented as mean \pm standard deviation. Categorical data were expressed as frequency and percentage. Values of $p<0.05$ were considered significant.

\section{RESULTS}

Of the 8063 patients who were admitted to our ICU during the 10-year study period (between 2007 and 2016), 616 $\mathbf{( 7 . 6 \% )}$ had thoracic trauma. After excluding pediatric cases (aged <18 years), the remaining 564 cases were included in the study sample. Figure $I$ is a schematic of patient selection. The median age (min-max) of the 564 patients who were eligible for this study was 43 (18-87) years. There were 133

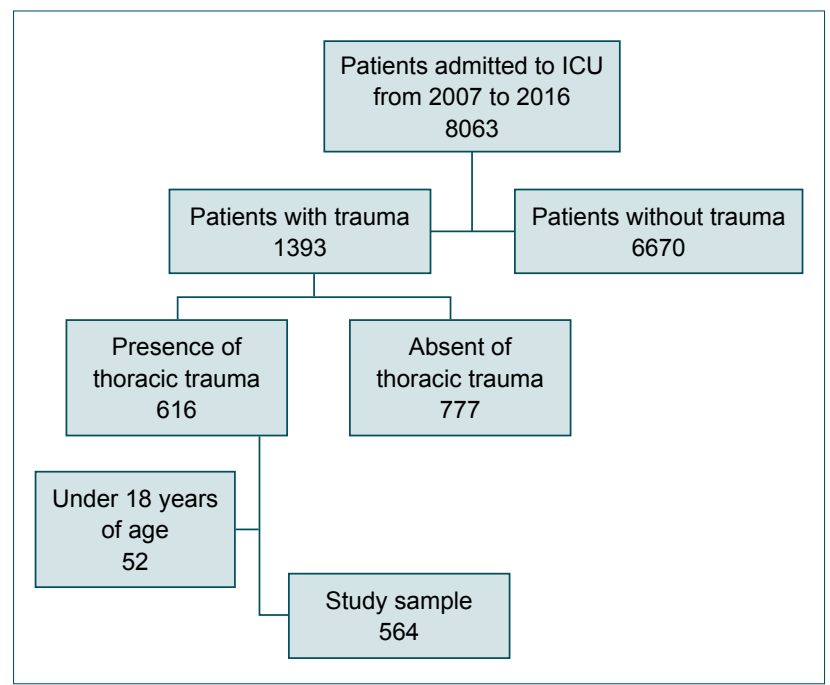

Figure 1. Study sample.

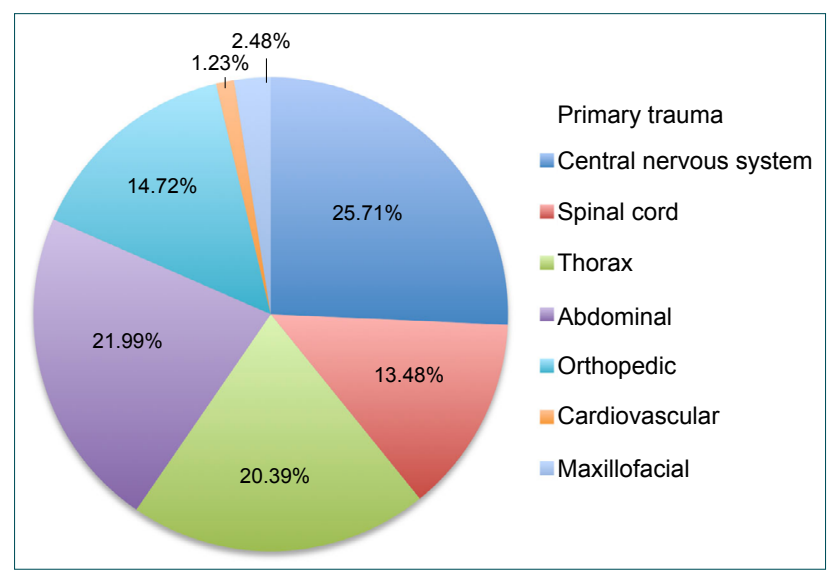

Figure 2. Distribution of patients according to primary trauma sites. 
(23.5\%) female and $43 \mathrm{I}$ (76.4\%) male patients. The patient distribution according to primary trauma site is presented in Figure 2. Mortality occurred in $159(28.1 \%)$ patients, while 405 (7I.8\%) were discharged. Among the fatal cases, 48 had sepsis, 28 were diagnosed with brain death, 25 developed hemorrhagic shock, 15 developed multiple organ dysfunction, 13 had ARDS, 10 developed malignant arrhythmia, seven developed disseminated intravascular coagulation, and 13 died due to sudden cardiac arrest as a result of clinical deterioration (due to various reasons).

\section{Data from Survival and Non-Survival Patient Subsets}

There were significant differences between the two groups with regards to median age, BUN, creatinine, GCS, RTS, ISS, and TRISS. Evaluation of patient outcomes revealed that the ICU stay length was significantly shorter among surviving patients $(p=0.007)$. Table I shows a summary of patient data on hospital admission.

There was no significant difference between the groups (survival, non-survival) regarding distribution of $\operatorname{sex}(p=0.44 \mathrm{I})$. Of the 405 surviving patients, 306 (71\%) were male, while I 25 of the 159 deceased patients $(29 \%)$ were male. Evaluation of trauma type as primary indication for the ICU admission revealed that patients with central nervous system (CNS) trauma had the highest mortality rate $(43.4 \%)$, while patients with maxillofacial trauma had the lowest mortality rate $(7.1 \%)$. Mortality differed significantly with respect to the primary trauma sites $(p<0.001)$. However, no significant difference was observed according to cause of trauma $(p=0.342)$. The data are summarized in Table 2.

Isolated thoracic trauma was present in only 30 (5.6\%) trauma cases. When compared groups as patients with isolated thoracic trauma and multitrauma, there was no statistically sig- nificant difference in demographic data (e.g., age, gender, comorbidities), hospital arrival laboratory parameters, trauma scores (ISS, RTS, and TRISS). There was no statistically significant difference between MV treatment and ICU mortality between two groups (respectively, $p=0.896, p=0.891$ ). A total of $7(23.3 \%)$ of the 30 patients with isolated thoracic trauma were operated, and 384 (71.9\%) of the 534 patients in the multitrauma group were operated. It was statistically significant $(\mathrm{p}<0.00 \mathrm{I})$. Evaluation according to thoracic trauma types revealed that mortality occurred in 77 of 233 (33\%) patients with pulmonary contusion, 108 of 389 (27.8\%) patients with rib fracture, 10 of $47(21.3 \%)$ patients with sternum fracture, II of 35 (3I.4\%) patients with diaphragmatic rupture, 49 of $170(28.8 \%)$ patients with hemothorax, 65 of 261 (24.9\%) patients with pneumothorax, 20 of 67 (29.9\%) patients with subcutaneous emphysema, 6 of 26 (23.1\%) patients with mediastinal trauma, I of 4 (25\%) patients with cardiac trauma, and 13 of 39 (33.3\%) patients with flail chest. Pulmonary contusion was seen significantly more frequently in the non-survival group $(p=0.032$ ) (Table 3$)$. In addition, the mortality rate was significantly higher among cases with the CNS trauma $(p<0.001)$. Other trauma types did not differ significantly in terms of mortality.

Forty-five (7.9\%) patients underwent thoracic surgery due to thoracic trauma. Of these patients, II (24.4\%) died, and $34(75.6 \%)$ were discharged from the ICU in a healthy state $(p=0.682)$. In addition, mortality occurred in $68(26.6 \%)$ of the $256(45.3 \%)$ patients who underwent tube thoracostomy $(p=0.433)$. All patients received passive oxygen support and underwent respiratory exercises.

Mortality occurred in 61 of $88(69.3 \%)$ patients who received inotrope/vasopressor, and mortality also occurred in 154 of 360 (42.8\%) patients who were mechanically ventilated. Among the deceased patients, the median MV length was 6.5

Table I. Data from surviving and deceased patients at the admission of hospital

\begin{tabular}{|c|c|c|c|c|}
\hline Parameter & Total $(n=564)$ & Survival $(n=405)$ & Non-survival $(n=159)$ & $\mathbf{p}$ \\
\hline Age* & $43(18-87)$ & $41(18-87)$ & $47(18-86)$ & 0.002 \\
\hline Sodium* & $138(125-155)$ & $138(126-155)$ & $138(125-153)$ & 0.391 \\
\hline Blood urea nitrogen* & I $6.2(5.3-89.4)$ & $15.8(5.3-45)$ & $17.6(6.7-89.4)$ & 0.01 \\
\hline Creatinine $^{*}$ & $0.95(0.2-8.9)$ & $0.93(0.2-8.9)$ & I.0I (0.5I-8) & $<0.001$ \\
\hline Hemoglobin & $11.02 \pm 2.64$ & $11.21 \pm 2.63$ & $11.02 \pm 2.64$ & 0.007 \\
\hline Platelet $^{*}$ & $203.5(16-615)$ & $207(19-486)$ & $194(16-615)$ & 0.146 \\
\hline Glasgow Coma Scale* & $15(3-15)$ & $15(3-15)$ & $3(3-15)$ & $<0.001$ \\
\hline Revised Trauma Score* & $7.84(0.73-7.84)$ & $7.84(0.73-7.84)$ & $2.93(0.73-7.84)$ & $<0.001$ \\
\hline Injury Severity Score ${ }^{*}$ & $17(2-75)$ & $14(2-36)$ & $29(14-75)$ & $<0.001$ \\
\hline Trauma and Injury Severity Score ${ }^{*}$ & $82.69(0.04-99.61)$ & $96.19(3.77-99.61)$ & $20.35(0.04-98.43)$ & $<0.001$ \\
\hline Intensive care unit stay length ${ }^{*}$ & $4.5(1-369)$ & $4(1-367)$ & $6(1-369)$ & 0.007 \\
\hline
\end{tabular}

*Shown as median (min-max). ${ }^{*}$ Shown as mean \pm standard deviation. Statistically significant difference between survival and non-survival groups are shown with bold characters. 
Table 2. Primary trauma site and cause of trauma among patients

\begin{tabular}{|c|c|c|c|c|c|c|c|}
\hline \multirow[t]{2}{*}{ Parameter } & \multicolumn{2}{|c|}{ Survival } & \multicolumn{2}{|c|}{ Non-Survival } & \multicolumn{2}{|c|}{ Total } & \multirow[t]{2}{*}{$\mathbf{p}$} \\
\hline & $\mathbf{n}$ & $\%$ & $\mathbf{n}$ & $\%$ & $\mathbf{n}$ & $\%$ & \\
\hline \multicolumn{8}{|l|}{ Primary trauma } \\
\hline Central nervous system & 82 & $56.6^{a}$ & 63 & 43.4 & 145 & 100 & \\
\hline Spinal cord & 57 & $75^{a, b, c}$ & 19 & 25 & 76 & 100 & \\
\hline Thorax & 80 & $69.6^{\mathrm{a}, \mathrm{c}}$ & 35 & 30.4 & 115 & 100 & \\
\hline Abdominal & 94 & $75.8^{\mathrm{b}, \mathrm{c}}$ & 30 & 24.2 & 124 & 100 & \\
\hline Orthopedic & 73 & $88^{b}$ & 10 & 12 & 83 & 100 & \\
\hline Cardiovascular & 6 & $85.7^{a, b, c}$ & 1 & 14.3 & 7 & 100 & \\
\hline Maxillofacial & 13 & $92.9^{a, b, c}$ & 1 & 7.1 & 14 & 100 & $<0.001$ \\
\hline \multicolumn{8}{|l|}{ Trauma cause } \\
\hline Motor vehicle accident & 281 & 71 & 115 & 29 & 396 & 100 & \\
\hline Fall & 80 & 71.4 & 32 & 28.6 & 112 & 100 & \\
\hline Penetrating trauma & 28 & 84.8 & 5 & 15.2 & 33 & 100 & \\
\hline Other blunt trauma & 16 & 69.6 & 7 & 30.4 & 23 & 100 & 0.342 \\
\hline
\end{tabular}

(I-I77) days, while the median MV length among the surviving patients was $5.5(1-16 I)$ days $(p=0.200)$. Mortality was higher in those who received inotrope/vasopressor or MV support at any time during their ICU stay ( $p<0.00$ I for both).

Evaluation of treatments and mortality rates among the 564 patients included in this study revealed that mortality occurred in 91 of the 391 (23.3\%) patients who underwent any kind of surgery, and mortality was significantly lower in the group of patients who underwent surgery when compared to patients who did not undergo surgery $(p<0.001)$.

\section{TRISS Score ROC Analysis}

The AUC-ROC for mortality for TRISS was $0.922(95 \% \mathrm{Cl}$ : 0.899-0.946). The ROC analysis using a TRISS cut-off score of 59.93 yielded a sensitivity and specificity of 0.88 and 0.87 , respectively, for mortality development. With this cut-off level (59.93), the degree of agreement between TRISS and mortality was $87.4 \%$, the positive predictive value was $72.92 \%$, and the negative predictive value was $94.89 \%$ (Fig. 3).

\section{Mortality Predictors (Univariate and Multivariate Logistic Regression Analysis)}

To determine predictors of mortality, a univariate analysis including demographic data, other accompanying traumas, type of thoracic trauma, and comorbidities was performed. Results of the univariate analysis revealed that age, presence of accompanying CNS trauma, pulmonary contusion, hypertension, and coronary artery disease were identified as significant predictors of mortality. Results are shown in Table 4.
Although the presence of hypertension and coronary artery disease were found to be significant factors in univariate analysis, they were not significant predictors of mortality in multivariate regression analysis. In multivariate regression analysis, each age increment was associated with a 1.025 -fold increase in odds of mortality, while the presence of CNS trauma was associated with a 2.147-fold increase, and the presence of pulmonary contusion was associated with a 1.752-fold increase in odds of mortality. Results are shown in Table 5.

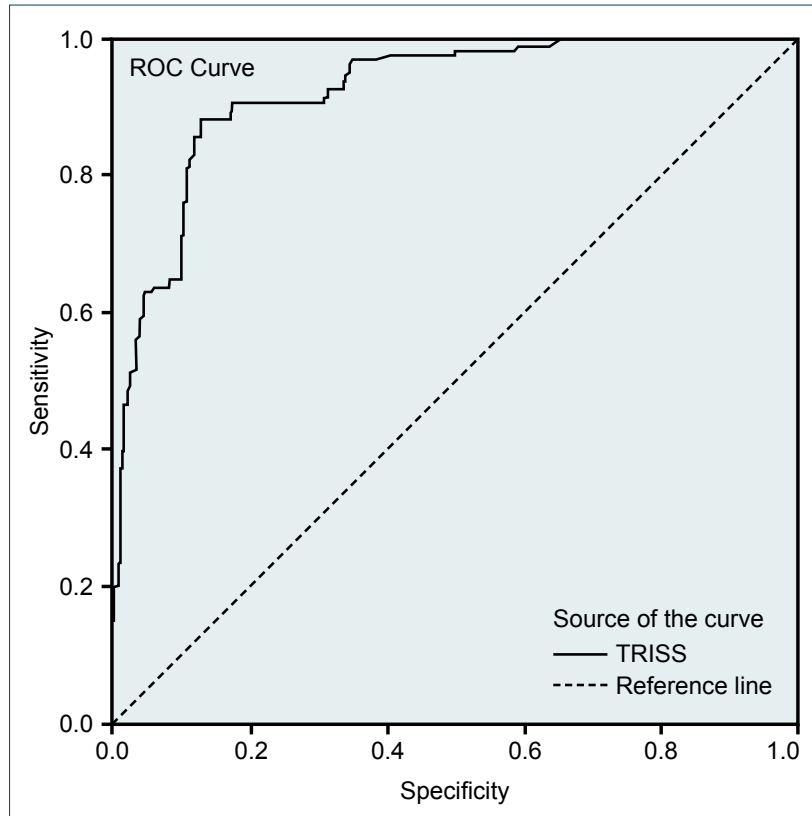

Figure 3. TRISS score ROC analysis (TRISS: Trauma and injury severity score; ROC: reciever operator characteristics). 
Table 3. Association between thoracic trauma type and mortality

\begin{tabular}{|c|c|c|c|c|c|c|c|}
\hline \multirow[t]{2}{*}{ Thoracic trauma sites } & \multicolumn{2}{|c|}{ Survival } & \multicolumn{2}{|c|}{ Non-Survival } & \multicolumn{2}{|c|}{ Total } & \multirow[t]{2}{*}{$\mathbf{p}$} \\
\hline & $\mathbf{n}$ & $\%$ & $\mathbf{n}$ & $\%$ & $\mathbf{n}$ & $\%$ & \\
\hline \multicolumn{8}{|l|}{ Pulmonary contusion } \\
\hline No & 249 & 75.2 & 82 & 24.8 & 331 & 100 & \\
\hline Yes & 156 & 67 & 77 & 33 & 233 & 100 & 0.032 \\
\hline \multicolumn{8}{|l|}{ Rib fracture } \\
\hline No & 124 & 70.9 & 51 & 29.1 & 175 & 100 & \\
\hline Yes & 281 & 72.2 & 108 & 27.8 & 389 & 100 & 0.736 \\
\hline \multicolumn{8}{|l|}{ Sternum facture } \\
\hline No & 368 & 71.2 & 149 & 28.8 & 517 & 100 & \\
\hline Yes & 37 & 78.7 & 10 & 21.3 & 47 & 100 & 0.352 \\
\hline \multicolumn{8}{|l|}{ Diaphragmatic rupture } \\
\hline No & 381 & 72 & 148 & 28 & 529 & 100 & \\
\hline Yes & 24 & 68.6 & 11 & 31.4 & 35 & 100 & 0.806 \\
\hline \multicolumn{8}{|l|}{ Hemothorax } \\
\hline No & 284 & 72.1 & 110 & 27.9 & 394 & 100 & \\
\hline Yes & 121 & 71.2 & 49 & 28.8 & 170 & 100 & 0.827 \\
\hline \multicolumn{8}{|l|}{ Pneumothorax } \\
\hline No & 209 & 69 & 94 & 31 & 303 & 100 & \\
\hline Yes & 196 & 75.1 & 65 & 24.9 & 261 & 100 & 0.107 \\
\hline \multicolumn{8}{|l|}{ Subcutaneous emphysema } \\
\hline No & 358 & 72 & 139 & 28 & 497 & 100 & \\
\hline Yes & 47 & 70.1 & 20 & 29.9 & 67 & 100 & 0.86 \\
\hline \multicolumn{8}{|l|}{ Mediastinal trauma } \\
\hline No & 385 & 71.6 & 153 & 28.4 & 538 & 100 & \\
\hline Yes & 20 & 76.9 & 6 & 23.1 & 26 & 100 & 0.710 \\
\hline \multicolumn{8}{|l|}{ Cardiac trauma } \\
\hline No & 402 & 71.8 & 158 & 28.2 & 560 & 100 & \\
\hline Yes & 3 & 75 & 1 & 25 & 4 & 100 & 1.000 \\
\hline \multicolumn{8}{|l|}{ Flail chest } \\
\hline No & 379 & 72.2 & 146 & 27.8 & 525 & 100 & \\
\hline Yes & 26 & 66.7 & 13 & 33.3 & 39 & 100 & 0.579 \\
\hline
\end{tabular}

Statistically significant differences between Survival and Non-Survival groups are shown in bold.

\section{DISCUSSION}

In this study, we sought to determine whether mortality could be predicted using information that does not require any calculation and is readily available at the time of ICU admission (e.g., type of thoracic trauma, accompanying traumas, comorbid states, age, and sex). The primary goal of this study was to identify clinical data that can be used to determine prognosis upon ICU admission. Univariate analyses revealed that age, presence of accompanying CNS trauma, pulmonary contusion, hypertension, and coronary artery disease were significant predictors of mortality in patients with trauma in the ICU. With multivariate regression analysis, each age in- crement was associated with a I.0-fold increase in mortality risk, the presence of CNS trauma was associated with a 2.1fold increase, and the presence of pulmonary contusion was associated with a I.7-fold increase in mortality odds.

Nearly $25 \%$ of all trauma-associated deaths are due to thoracic injuries, and thoracic injuries have the highest complication rates among all trauma types. ${ }^{[13]}$ In this study, during a 10-year period, $564(40.4 \%)$ patients admitted to the ICU had thoracic trauma, and among these, II 5 (20.39\%) patients had thoracic trauma as their primary indication for the ICU admission. The median age of the patients included in this study 
Table 4. Univariate logistic regression analyses

\begin{tabular}{|c|c|c|c|}
\hline & Odds ratio & $\mathbf{9 5 \%}$ Confidence interval & $\mathbf{p}$ \\
\hline \multicolumn{4}{|l|}{ Demographic properties } \\
\hline Age & 1.019 & $1.008-1.030$ & $<0.001$ \\
\hline Sex (male) & 1.189 & $0.765-1.850$ & 0.441 \\
\hline \multicolumn{4}{|l|}{ Accompanying trauma } \\
\hline Central nervous system trauma & 2.020 & $1.390-2.935$ & $<0.001$ \\
\hline Abdominal trauma & 0.972 & $0.647-1.459$ & 0.890 \\
\hline Orthopedic trauma & 0.743 & $0.512-1.080$ & 0.119 \\
\hline Aortic trauma & 1.735 & $0.696-4.328$ & 0.237 \\
\hline Spinal cord trauma & 1.116 & $0.772-1.613$ & 0.561 \\
\hline Isolated thoracic trauma & 1.097 & $0.491-2.450$ & 0.821 \\
\hline \multicolumn{4}{|l|}{ Type of thorax trauma } \\
\hline Pulmonary contusion & 1.499 & $1.035-2.170$ & 0.032 \\
\hline Rib fracture & 0.934 & $0.630-1.386$ & 0.736 \\
\hline Sternal fracture & 0.668 & $0.324-1.377$ & 0.274 \\
\hline Diaphragmatic rupture & 1.180 & $0.564-2.469$ & 0.661 \\
\hline Hemothorax & 1.046 & $0.702-1.557$ & 0.827 \\
\hline Pneumothorax & 0.737 & $0.509-1.069$ & 0.108 \\
\hline Subcutaneous emphysema & 1.096 & $0.627-1.916$ & 0.748 \\
\hline Mediastinal injury & 0.755 & $0.297-1.916$ & 0.554 \\
\hline Cardiac injury & 0.848 & $0.088-8.214$ & 0.887 \\
\hline Flail chest & 1.298 & $0.649-2.594$ & 0.461 \\
\hline \multicolumn{4}{|l|}{ Comorbidities } \\
\hline Hypertension & 2.063 & I.102-3.862 & 0.024 \\
\hline Cardiac failure & 7.769 & $0.802-7.254$ & 0.077 \\
\hline Coronary artery disease & 4.351 & I.027-I.425 & 0.046 \\
\hline Arrhythmia & 2.557 & $0.159-4.129$ & 0.508 \\
\hline Chronic obstructive pulmonary disease & 1.707 & $0.283-1.313$ & 0.560 \\
\hline Asthma & 2.577 & $0.515-12.904$ & 0.249 \\
\hline Chronic renal failure & 5.146 & $0.463-57.159$ & 0.182 \\
\hline Diabetes mellitus & 1.714 & $0.831-3.535$ & 0.145 \\
\hline Malignancy & 2.567 & $0.358-18.381$ & 0.348 \\
\hline
\end{tabular}

Statistically significant differences are shown in bold.

was 43 (min-max 18-87) years, which was consistent with the literature, and the majority of the patients were male. [14-20] Previous reports have shown that mortality rates in patients with thoracic trauma are markedly high (up to $30 \%$ ). ${ }^{[21]}$ Emircan et al. ${ }^{[22]}$ reported a $22 \%$ mortality rate among patients presenting to the emergency department with thoracic trauma. However, in other studies, the mortality rate varies between $9.4 \%$ and $20 \% .{ }^{[23]}$ Although there are limited publications regarding ICU mortality, this study found a similar mortality rate among thoracic trauma cases (28.1\%).

The severity of thoracic traumas depends on the type of trauma and on the severity of any accompanying traumas.
Previous studies have shown that thoracic trauma cases with accompanying head trauma had greater mortality rates than those without it. ${ }^{[24,25]}$ In this study, only 30 (5.6\%) cases had isolated thoracic trauma. Of the patients in this study with accompanying traumas, only those with accompanying CNS trauma had significantly higher mortality rates. Lin et al. reported that $36.3 \%$ of cases presenting to the emergency department with thoracic trauma required intensive care. As in our study, the study by Lin et al. ${ }^{[26]}$ found that those thoracic trauma cases with accompanying head trauma required intensive care and had prolonged ICU stays, more so than most of the other thoracic trauma cases. However, in that same study, it was reported that the presence of hemothorax in thoracic 
Table 5. Multivariate logistic regression analyses

\begin{tabular}{lccc}
\hline & OR & $95 \% \mathbf{C l}$ & p \\
\hline Age & 1.025 & $1.012-1.038$ & $<0.001$ \\
CNS trauma & 2.147 & $1.441-3.198$ & $<0.001$ \\
Pulmonary contusion & 1.752 & $1.162-2.642$ & 0.007 \\
Hypertension & 1.414 & $0.695-2.879$ & 0.339 \\
Coronary artery disease & 3.274 & $0.720-14.879$ & 0.125 \\
\hline
\end{tabular}

Statistically significant differences are shown in bold.

OR: Odds ratio; Cl: Confidence interval; CNS: Central nervous system.

traumas was associated with the greatest requirement for intensive care. Interestingly, in this study, which included a large patient population, only the presence of pulmonary contusion was found to be associated with mortality. Other conditions that can cause serious respiratory distress (e.g., diffuse hemothorax or flail chest) were not found to be associated with mortality. This may be due to the emergent treatment of hemothorax with surgery or chest tube drainage, and because patients with flail chest often undergo surgical stabilization in the early period. A large study by Horst et al. ${ }^{[19]}$ included over 10 years of experience regarding patients with serious thoracic trauma. In that study, over those 10 years, there was a decrease in the requirement of those patients for urgent surgery, as well as in ventilation time, ICU stay length, and rate of respiratory failure development. The authors explained that these decreases were most likely due to recent advances in diagnostic methods and treatment strategies. Pulmonary contusion occurs in approximately $30 \%-75 \%$ of blunt thoracic traumas caused by motor vehicle accidents. ${ }^{[27]}$ Pulmonary contusion requires close monitoring, as pulmonary contusion-associated mortality rates vary between $6 \%$ and $25 \%$, and the clinical situation is often accompanied by pneumonia or acute respiratory distress syndrome. ${ }^{[15,17]}$ One study reported that 5 of $16 \mathrm{ICU}$ patients (3I.2\%) with pulmonary contusion died. Importantly, the authors of that study found that the APACHE II score, the SAPS II score, the SOFA score, the $\mathrm{PaO}_{2} / \mathrm{FiO}_{2}$ ratio, and ventilator days were correlated with mortality. ${ }^{[14]}$ It is important to note that pulmonary contusion may not manifest itself clinically or radiologically within the first few days following trauma. However, as is the case with any soft tissue contusion, the extent of injury may progress over time, and therefore, the patient should be inspected throughout his or her hospital stay for the development of respiratory failure.

In this study, thoracic injuries were most frequently caused by motor vehicle accidents (70.2\%), followed by fall from height (19.8\%). In developing countries, particularly rapidly developing Middle Eastern countries, mortality due to motor vehicle accidents has become a more important problem due to an increase in the number of speeding vehicles. ${ }^{[28]}$ In this study, the most frequent type of trauma associated with motor vehicle accidents was rib fracture, followed by pulmonary contusion, pneumothorax, hemothorax, subcutaneous emphysema, sternum fracture, flail chest, mediastinal injuries, and cardiac injury, respectively. In the emergency department, patients must be evaluated according to the severity of their injuries. Further, admission and treatment should start as soon as possible to reduce mortality rates. In addition, the presence of comorbidities may contribute to clinical deterioration. In this study, while comorbid hypertension and coronary artery disease were found to be associated with mortality in univariate analysis, they were not found to be significant risk factors in multivariate analysis. However, our study sample mainly included young adults with a low number of comorbidities, and therefore, we believe a larger study sample is required to validate these results.

Following trauma, the ability to predict patient outcomes is important not only for clinicians, but for the patients and their families as well. Therefore, several trauma-scoring systems have been developed for this purpose. RTS is a physiological scoring system that has been proven for its accuracy in predicting mortality. It is based on GCS, SBP, and RR parameters. Next, ISS was developed for patients with multiple traumas, and is an anatomical scoring system. TRISS is based on ISS, RTS, and patient age, and is used to predict survival after trauma. ${ }^{[2]}$ TRISS combines both anatomical and physiological aspects, and has been proven to be a good predictor of survival in patients with trauma. In a study that retrospectively evaluated 140 patients with thoracic trauma, Bellone et al. ${ }^{[16]}$ reported that only 10 of those 140 patients $(7.1 \%)$ were admitted to the ICU due to clinical and radiological deterioration. In univariate and multivariate analyses, the authors of that study found that increasing orthopnea and trauma scores could be used to predict intensive care requirement. In this study, we found a significant difference between the surviving and deceased groups of patients in terms of ISS, RTS, and TRISS scores. In this study, a TRISS cut-off score of 59.93 yielded $88 \%$ sensitivity and $87 \%$ specificity for predicting mortality, and was found to be strongly associated with mortality. Similarly, Esme et al. ${ }^{[18]}$ performed a risk assessment with TRISS in 152 patients with blunt thoracic trauma, and identified that the TRISS scoring system was an independent risk factor for predicting mortality. Darbandsar Mazandarani et al. ${ }^{[30]}$ evaluated patients with trauma in the emergency department with the TRISS score, and reported that the best cut-off point for TRISS mortality prediction was $13.2 \%$ (sens.=76.52\%; spec.=95.65\%). Another study reported that the cut-off point for TRISS was 85. ${ }^{[22]}$ Although there are variations in the reported TRISS cut-off values, in general, we believe that the TRISS scoring system can be used to predict mortality in thoracic trauma.

GCS is another scoring system that has long been used to predict mortality in patients with trauma. As expected, these data revealed a significant difference in GCS between the surviving and deceased groups of patients, with surviving 
patients having significantly higher median scores $(p<0.00 \mathrm{I})$. Wang et al. ${ }^{[20]}$ evaluated 127 patients with chest trauma, and results indicated that a lower GCS, lower oxygenation ratio, and the presence of shock were independent predictors of mortality in patients with blunt thoracic injuries.

As expected, in this study, we found markedly increased mortality rates among patients requiring $\mathrm{MV}$ or inotrope/vasopressor support ( $<<0.00 \mathrm{I}$ for both). Indeed, previous studies have shown that $M V$ time is associated with trauma severity and the development of complications. ${ }^{[31,32]}$

There are several limitations associated with this study. First, this study has a retrospective and single-centered design. Second, the study sample comprised only of patients who were admitted to the Anesthesiology and Reanimation ICU. Since cardiac or major cardiovascular injuries are typically followed by cardiovascular surgery, there were no such patients in this study sample. Third, because of this study's retrospective design, MV parameters could not be closely monitored in patients requiring $\mathrm{MV}$ and also APACHE II and SOFA scores were not given due to scores could not be obtained from all patients over a I0-year follow-up period.

\section{Conclusion}

Mortality can be predicted in patients with thoracic trauma who are admitted to the ICU without the use of any invasive interventions or calculations; these predictions can be made by accounting only for clinical and demographic properties, trauma types, and comorbid states. The results of this study indicate that advanced age, pulmonary contusion, and accompanying CNS trauma are independent risk factors for predicting ICU mortality in patients with thoracic trauma. Our noninvasive approach is further supported with the TRISS scores, which is one of the latest scoring systems used to predict mortality in patients with trauma. Prompt diagnosis, close monitoring, and early therapeutic interventions can help to reduce mortality rates in such patients.

\section{Conflict of interest: None declared.}

\section{REFERENCES}

1. Hodgson NF, Stewart TC, Girotti MJ. Autopsies and death certification in deaths due to blunt trauma: what are we missing? Can J Surg 2000;43:130-6.

2. Arajarvi E, Santavirta S, Tolonen J. Aortic ruptures in seat belt wearers. J Thorac Cardiovasc Surg 1989;98:355-61.

3. O'Connor JV, Adamski J. The diagnosis and treatment of non-cardiac thoracic trauma. J R Army Med Corps 2010;156:5-14. [CrossRef]

4. Santavirta S, Arajärvi E. Ruptures of the heart in seatbelt wearers. J Trauma 1992;32:275-9. [CrossRef]

5. Shorr RM, Crittenden M, Indeck M, Hartunian SL, Rodriguez A. Blunt thoracic trauma. Analysis of 515 patients. Ann Surg 1987;206:200-5.

6. Simon BJ, Cushman J, Barraco R, Lane V, Luchette FA, Miglietta M, et al; EAST Practice Management Guidelines Work Group.. Pain manage- ment guidelines for blunt thoracic trauma. J Trauma 2005;59:1256-67.

7. Stewart RM, Corneille MG. Common complications following thoracic trauma: their prevention and treatment. Semin Thorac Cardiovasc Surg 2008;20:69-71. [CrossRef]

8. Dimopoulou I, Anthi A, Lignos M, Boukouvalas E, Evangelou E, Routsi C, et al. Prediction of prolonged ventilatory support in blunt thoracic trauma patients. Intensive Care Med 2003;29:1101-5. [CrossRef]

9. Günay K. Thorax Traumas. In: Ertekin C, Kurdoğlu M, Taviloğlu K, editors. Book Of Trauma and Resuscitation Course. Istanbul: Logos Yayıncilık; 2006. p. 87-102.

10. Greaves I, Porter K, Ryan J. Thoracic Trauma. In: Trauma Care Manuel. New York: Oxford University Press Inc; 2001. p. 54-70.

11. Boyd CR, Tolson MA, Copes WS. Evaluating trauma care: the TRISS method. Trauma Score and the Injury Severity Score. J Trauma 1987;27:370-8. [CrossRef]

12. Champion HR, Sacco WJ, Copes WS, Gann DS, Gennarelli TA, Flanagan ME. A revision of the Trauma Score. J Trauma 1989;29:623-9.

13. Lancey RA, Monahan TS. Correlation of clinical characteristics and outcomes with injury scoring in blunt cardiac trauma. J Trauma 2003;54:509-15. [CrossRef]

14. Alisha C, Gajanan G, Jyothi H. Risk Factors Affecting the Prognosis in Patients with Pulmonary Contusion Following Chest Trauma. J Clin Diagn Res 2015;9:OC17-9. [CrossRef]

15. Allen GS, Coates NE. Pulmonary contusion: a collective review. Am Surg 1996;62:895-900.

16. Bellone A, Bossi I, Etteri M, Cantaluppi F, Pina P, Guanziroli M, et al. Factors Associated with ICU Admission following Blunt Chest Trauma. Can Respir J 2016;2016:3257846. [CrossRef]

17. Cohn SM. Pulmonary contusion: review of the clinical entity. J Trauma 1997;42:973-9. [CrossRef]

18. Esme H, Solak O, Yurumez Y, Yavuz Y, Terzi Y, Sezer M, et al. The prognostic importance of trauma scoring systems for blunt thoracic trauma. Thorac Cardiovasc Surg 2007;55:190-5. [CrossRef]

19. Horst K, Andruszkow H, Weber CD, Pishnamaz M, Herren C, Zhi Q, et al. Thoracic trauma now and then: A 10 year experience from 16,773 severely injured patients. PLoS One 2017;12:e0186712. [CrossRef]

20. Wang SH, Wei TS, Chen CP. Prognostic analysis of patients with blunt chest trauma admitted to an intensive care unit. J Formos Med Assoc 2007;106:444-51. [CrossRef]

21. Waydhas C. Thoracic trauma [Article in German]. Unfallchirurg 2000;103:871-89. [CrossRef]

22. Emircan Ş, Özgüç H, Aydın ŞA, Özdemir F, Köksal Ö, Bulut M. Factors affecting mortality in patients with thorax trauma. Ulus Travma Acil Cerrahi Derg 2011;17:329-33. [CrossRef]

23. Champion HR, Sarıbeyoglu K. Trauma score. In: Ertekin C, Taviloğlu K, Kurdoğlu M, Güloğlu R, editors. Trauma. 1st ed. Istanbul: Istanbul Medikal; 2005. p. 72-82.

24. Al-Koudmani I, Darwish B, Al-Kateb K, Taifour Y. Chest trauma experience over eleven-year period at al-mouassat university teaching hospital-Damascus: a retrospective review of 888 cases. J Cardiothorac Surg 2012;7:35. [CrossRef]

25. El-Menyar A, Latifi R, AbdulRahman H, Zarour A, Tuma M, Parchani A, et al. Age and traumatic chest injury: a 3-year observational study. Eur J Trauma Emerg Surg 2013;39:397-403. [CrossRef]

26. Lin FC, Tsai SC, Li RY, Chen HC, Tung YW, Chou MC. Factors associated with intensive care unit admission in patients with traumatic thoracic injury. J Int Med Res 2013;41:1310-7. [CrossRef]

27. Tyburski JG, Collinge JD, Wilson RF, Eachempati SR. Pulmonary contu- 
sions: quantifying the lesions on chest $\mathrm{X}$-ray films and the factors affecting prognosis. J Trauma 1999;46:833-8. [CrossRef]

28. Mamtani R, Al-Thani MH, Al-Thani AA, Sheikh JI, Lowenfels AB. Motor vehicle injuries in Qatar: time trends in a rapidly developing Middle Eastern nation. Inj Prev 2012;18:130-2. [CrossRef]

29. Schluter PJ, Nathens A, Neal ML, Goble S, Cameron CM, Davey TM, et al. Trauma and Injury Severity Score (TRISS) coefficients 2009 revision. J Trauma 2010;68:761-70. [CrossRef]

30. Darbandsar Mazandarani P, Heydari K, Hatamabadi H, Kashani P, Jamali Danesh Y. Acute Physiology and Chronic Health Evaluation
(APACHE) III Score compared to Trauma-Injury Severity Score (TRISS) in Predicting Mortality of Trauma Patients. Emerg (Tehran) 2016;4:88-91.

31. Huber S, Biberthaler P, Delhey P, Trentzsch H, Winter H, van Griensven $\mathrm{M}$, et al; Trauma Register DGU. Predictors of poor outcomes after significant chest trauma in multiply injured patients: a retrospective analysis from the German Trauma Registry (Trauma Register DGU ${ }^{\odot}$ ). Scand J Trauma Resusc Emerg Med 2014;22:52. [CrossRef]

32. Michelet P, Couret D, Bregeon F, Perrin G, D'Journo XB, Pequignot V, et al. Early onset pneumonia in severe chest trauma: a risk factor analysis. J Trauma 2010;68:395-400. [CrossRef]

\section{ORIJINAL ÇALIŞMA - ÖZET}

\section{Yoğun bakım ünitesine başvuran toraks travmalı olguların prognostik değerlendirmesi: On yıllık sonuçlar \\ Dr. Mehtap Pehlivanlar Küçük, ${ }^{1}$ Dr. Ahmet Oğuzhan Küçük, ${ }^{2}$ Dr. İskender Aksoy, ${ }^{3}$ Dr. Davut Aydın, ${ }^{1}$ Dr. Fatma Ülger ${ }^{1}$}

1Ondokuz Mayıs Üniversitesi Tıp Fakültesi, Anesteziyoloji ve Reanimasyon Anabilim Dalı, Yoğun Bakım Bilim Dalı, Samsun ${ }^{2}$ Karadeniz Teknik Üniversitesi Tıp Fakültesi, Anesteziyoloji ve Reanimasyon Anabilim Dalı, Yoğun Bakım Bilim Dalı, Trabzon ${ }^{3}$ Ondokuz Mayıs Üniversitesi Tıp Fakültesi, Acil Tıp Anabilim Dalı, Samsun

AMAÇ: Çoklu travmalar ülkemizde ve dünyada özellikle genç erişkinlerin ölüm nedenlerinin başında gelmektedir. Bu çalısmanın amacı yoğun bakımlarda takip edilmekte olan izole ya da diğer organ yaralanmaları ile birlikte olan toraks travmalı olgularda mortalite için bağımsız prognostik faktörlerinin predikte edilmesidir.

GEREÇ VE YÖNTEM: Bu çalışmada, 2007-2016 yılları arasında yoğun bakım ünitemizde takip edilmiş olan toraks travmalı hastaların verileri geriye dönük olarak incelendi. Bu yıllar içerisinde yoğun bakım hasta kayıt sisteminde yer alan 8063 hasta arasından verilerine sağlıklı bir şekilde ulaşılan 616 toraks travma hastası saptandı. On sekiz yaş altı olgular dışlanarak kalan 564 hasta çalışma grubu hastası olarak belirlendi.

BULGULAR: Çalışmaya alınan 8063 hastanın 6I6'sında (\%7.6) toraks travması saptandı. Çalışma kriterlerini sağlayan 564 çalışma grubu hastasının yaş ortalaması medyan (min-maks) 43 (I8-87) idi. Hastaların I59'u (\%28.I) mortalite ile sonlanırken 405'i (\%7I.8) yoğun bakım ünitesinden taburcu edildi. Travma ve Yaralanma Şiddeti Skoru'nun (TRISS) mortalite takibi için, AUC değeri: 0.922 (\%95 Cl: 0.899-0.946) idi. ROC analizine göre mortalite gelişme olasılığı için TRISS skoru 59.93 sınır kabul edildiğinde (Sensitivite; 0.88, Spesifisite: 0.87) olarak tespit edildi. Multivaryant lojistik regresyon analizinde mortaliteyi ön görmede her bir yaş artış mortalitede 1.025 kat, santral sinir sistemi travması varlığı mortalitede 2.147 kat, pulmoner kontüzyo varlığı mortalitede 1.752 kat artışla ilişkiliydi.

TARTIŞMA: Bu çalışmanın sonuçları ile toraks travma hastalarında ileri yaş, pulmoner kontüzyon ve eşlik eden santral sinir sistemi travması yoğun bakım mortalitesini göstermede bağımsız birer risk faktörü olarak tanımlanmıştır. Travma hastalarında en güncel skorlama sistemlerinden olan TRISS skoru da bu non-invaziv yaklaşımımızı desteklemektedir.

Anahtar sözcükler: Göğüs; hastane mortalite; toraks travma; torasik yaralanma; TRISS; yoğun bakım ünitesi.

Ulus Travma Acil Cerrahi Derg 2019;25(I):46-54 doi: 10.5505/tites.20।8.97345 